\title{
Pemanfaatan Teknologi Informasi dan Komunikasi dalam Industri Fashion Indonesia
}

\author{
Tika Diyanti Mustikarani ${ }^{1 *}$, Irwansyah ${ }^{2}$ \\ ${ }^{1,2}$ Departemen Ilmu Komunikasi - Universitas Indonesia \\ Jalan Salemba Raya No. 4, Jakarta Pusat 10430 - Indonesia \\ *Email korespondensi: diantymustikarani@gmail.com
}

\begin{abstract}
In the current economic development, technological knowledge in ICTs plays a very important role in the growth and competitiveness of organizations. In the creative economy sector, fashion subsector is the second largest contributor. But unfortunately, the use of information and communication technology in the fashion industry in Indonesia has not used ICTs to the full. Today fashion is no longer just about clothing, but a lifestyle that cannot be separated from modern humans. In the fashion industry, innovation is an important factor in consumer purchasing decisions. This conceptual article provides an overview of the application of ITK in the concept of e-commerce, big data analytics and user experience that has proven to be able to influence the development of the fashion industry in Indonesia.
\end{abstract}

Keywords: ICT, Fashion, E-Commerce, Big Data Analytics, User Experience

\begin{abstract}
Abstrak
Dalam perkembangan ekonomi saat ini, pengetahuan teknologi informasi dan komunikasi (TIK) memainkan peran yang sangat penting dalam pertumbuhan dan daya saing organisasi. Pada sektor ekonomi kreatif, subsektor fashion merupakan pemberi kontribusi nomor dua terbesar. Namun sayangnya pemanfaatan teknologi informasi dan komunikasi dalam industri fashion di Indonesia nyatanya belum menggunakan TIK secara maksimal. Saat ini fashion bukan lagi hanya tentang pakaian, melainkan gaya hidup yang tidak dapat terlepas dari manusia modern. Dalam industri fashion, inovasi merupakan faktor penting dalam keputusan pembelian konsumen. Artikel konseptual ini memberikan gambaran mengenai penerapan ITK dalam konsep e-commerce, big data analytics dan user experience yang terbukti mampu memberikan pengaruh dalam pengembangan industri fashion di Indonesia.
\end{abstract}

Kata Kunci: Teknologi Informasi dan Komunikasi, Fashion, E-Commerce, Big Data Analytics, User Experience

\section{PENDAHULUAN}

Teknologi informasi dan komunikasi (TIK) di Indonesia saat ini terus berkembang dan telah digunakan oleh banyak organisasi. Perkembangan TIK telah membawa organisasi pada cara baru dalam menyimpan, memproses, mendistribusikan dan bertukar informasi (Kollberg \& Dreyer, 2006). Adaptasi TIK dalam organisasi telah memberikan hasil positif dalam peningkatan kinerja organisasi. Dalam hal operasional, struktural dan strategi organisasi, telah menghasilkan efisiensi dan memberikan pengalaman belanja konsumen yang lebih baik (Setiowati, Hartoyo, Daryanto, \& Arifin, 2015). Dalam perkembangan ekonomi saat ini, pengetahuan TIK memainkan peran yang sangat penting dalam pertumbuhan dan daya saing organisasi (Lee, Kim, \& Park, 2009).

Industri kreatif memiliki peran penting dalam pertumbuhan ekonomi di Indonesia. Badan Pusat Statistik (BPS) tahun 2013 menyatakan, pertumbuhan industri kreatif mencapai 7,6 persen dan menghasilkan Rp 641,82 triliun. Hal tersebut menunjukkan, industri kreatif memberikan pengaruh pada kenaikan Gross Domestic Product (GDP) Indonesia. Potensi industri ini diharapkan terus tumbuh, seperti tertera dalam blueprint industri kreatif Indonesia. Industri ini ditargetkan memberi kontribusi 11-12\% GDP pada 2025 (Hendrayati \& Gaffar, 2016).

Menurut data BPS pada tahun 2013, industri fashion menguasai 28,29 persen dari total industri kreatif di Indonesia (Hendrayati \& Gaffar, 2016). Di Indonesia, industri fashion termasuk dalam satu dari 16 kelompok industri ekonomi kreatif (Kemenperin: Perluas Pasar Industri Fesyen Dalam Negeri Lewat Indonesia Fashion Week 2018). Kementerian Perdagangan Indonesia 
mendefinisikan subsektor fashion sebagai semua bentuk kreativitas yang berhubungan dengan kreasi desain pakaian, sepatu, aksesoris fashion, pakaian jadi dan produksi aksesoris serta distribusi produk fashion yang dibagi dalam kategori perusahaan fashion, distributor fashion, produksi massa, readyto-wear dan haute couture (Setiowati et al., 2015).

Fashion dinilai tidak hanya sebagai industri pakaian yang merupakan kebutuhan dasar manusia. Lebih dari itu, fashion menunjukkan gaya hidup seseorang dalam penampilan dan menjadi bagian dari identitas diri dan kelompok. Industri fashion juga memiliki peran penting karena kontribusinya yang sangat besar terhadap perekonomian (Saraswati, 2018, Rachmawati, 2018). Karena besarnya kemampuan industri fashion dalam meningkatkan pendapatan nasional dan nilai ekspor, fashion menjadi subsektor yang dinggulkan dalam ekonomi kreatif Indonesia (Ekonomi Kreatif \& Outlook, 2019). Namun berdasarkan data Badan Ekonomi Kreatif ("BEKRAF Data," n.d.), pada tahun 2016, diketahui jumlah usaha atau perusahaan ekonomi kreatif yang memanfaatkan media internet dan penerapan e-commerce pada subsektor fashion yaitu sebesar 51,210 dari total 89,685 perusahaan, sehingga masih ada 38,475 perusahaan yang belum memanfaatkan TIK dalam kegiatan usahanya.

Dalam hal ini perlu diperhatikan kemampuan industri fashion Indonesia dalam berkompetisi di pasar global. Kebutuhan akan TIK sebagai faktor pendukung dapat meningkatkan aktivitas bisnis yang efektif. Apabila industri ekonomi kreatif di Indonesia menerapkan TIK dengan baik, maka hal ini akan mampu meningkatkan kemampuan dalam berkompetisi di pasar global. Seperti misalnya salah satu penggunaan TIK yang sudah umum digunakan dalam sektor ekonomi kreatif adalah electronic commerce atau e-commerce (Darwis, 2013). Saat ini setiap industri juga mulai bergerak lebih dekat dalam pemahaman dan pemanfaatan big data dalam menyelesaikan masalah. Karena analisis terhadap big data dapat memberikan banyak pengetahuan bernilai bagi perusahaan yang selanjutnya dapat digunakan untuk pengembangan perusahaan (Le \& Liaw, 2017).

Dalam kaitannya dengan pengembangan perusahaan, salah satu kunci kesuksesan juga terletak pada kemampuan perusahaan dalam memberikan pengalaman terbaik bagi pengguna produk atau jasanya. Dalam konteks TIK hal ini termasuk dalam konsep user experience (UX) yang saat ini juga banyak mendapat perhatian dalam fungsinya memberikan pengalaman terbaik bagi konsumen (Sproll, Peissner, \& Sturm, 2010).

Studi ini membahas tentang pemanfaatan TIK dalam industri fashion di Indonesia dengan fokus konsep TIK pada penggunaan e-commerce, big data analytics dan user experience. Tujuan penelitian adalah untuk memberikan gambaran mengenai hubungan antara pemanfaatan TIK dan perkembangan industri fashion di Indonesia. Konsep yang digunakan merupakan studi literatur beberapa jurnal penelitian yang membahas tentang e-commerce, big data analytics, user experience dan industri fashion di Indonesia.

\section{KERANGKA TEORI}

\section{E-Commerce}

The Organization for Economic Cooperartion and Development (OECD) mendefinisikan $e$ commerce sebagai pertukaran informasi elektronik yang mendukung dan mengendalikan aktivitas komersial diantaranya manajemen organisasi, manajemen bisnis, negosiasi, kontrak komersial, legal dan framework regulasi serta pengaturan keuangan dan pajak. Pengertian lain yaitu dari Learnth (2004) menyatakan bahwa e-commerce tidak hanya sekadar aktivitas penjualan dan pembelian secara online, tetapi termasuk semua bentuk aktivitas bisnis yang dilakukan di Internet (Ruikar, Kirti. Anumba, 2008).

Electronic commerce adalah sebuah konsep baru yang didefinisikan sebagai proses dalam penjualan atau pembelian barang dan jasa dengan menggunakan World Wide Web atau pembelian maupun pertukatan produk, jasa dan informasi melalui jaringan informasi internet (Darwis, 2013). Fross dan Strauss (2013) mengembangkan definisi e-commerce yang berfokus pada penjualan dan pembelian online, digital value creation, virtual market places, tampilan toko virtual dan perantara distribusi baru (Akter \& Wamba, 2016). 
Definisi lain datang dari Kalakota dan Whinston (1997) yang mendeskripsikan e-commerce sebagai metode elektronik dalam melakukan aktivitas bisnis, terutama dengan penggunaan internet. Secara luas, e-commerce juga dilihat sebagai metode bisnis modern yang ditujukan untuk memenuhi kebutuhan organisasi, penjual dan pembeli dengan tujuan efisiensi biaya sembari meningkatkan kualitas barang, jasa dan peningkatan kecepatan jasa pengantaran (Ruikar, Kirti. Anumba, 2008).

Dalam Ruikar dan Anumba (2008) e-commerce dapat di klasifikasikan dalam beberapa kategori berdasarkan fungsi bisnisnya, yaitu: (1) Business to Business (B2B); (2) Consumer to Consumer(C2C); (3) Administration to Administration (A2A); (4) Business to Consumer (B2C) atau Consumer to Business (C2B; (5) Business to Administration (B2A) atau Administration to Business (A2B); (6) Consumer to Administration (C2A) atau Administration to Consumer (A2C).

Pada perkembangannya, teknologi berbasis internet membuat e-commerce dapat memanfaatkan banyak hal transformatif seperti melakukan layanan pelanggan secara real-time, persaingan harga yang dinamis, penawaran produk yang dapat dibuat lebih personal atau peningkatan dalam kemudahan interaksi dengan konsumen. Dalam kaitannya pada pemanfaatan data yang terkumpul dalam platform e-commerce, pelaku usaha dapat melakukan analisis big data. Big data akan memberikan informasi untuk melihat perilaku konsumen dan mencari tahu bagaimana cara terbaik dalam membuat konsumen tetap setia menjadi pelanggan dan terus membeli barang (Akter \& Wamba, 2016).

\section{Big Data Analitycs}

Situs e-commerce setiap harinya menghasilkan data perilaku pengguna dalam jumlah yang sangat besar. Perusahaan berharap dapat memahami setiap pengguna melalui data-data ini dan selanjutnya dapat membangun sebuah hubungan dengan konsumen. Saat ini big data dapat menerjemahkan data konsumen menjadi bentuk pengetahuan yang bernilai ( $\mathrm{Hu}, 2018)$. Dalam laporan International Data Cooperation, pada tahun 2011 diestimasi data yang berhasil terkumpul di dunia sebesar 1,8 zettabytes dan pada tahun 2020 di prediksi akan mencapai lebih dari 35 zettabytes, sehingga dapat dikatakan, kita telah hidup dalam era big data (Le \& Liaw, 2017). Apabila perusahaan mampu menganalisis data yang dimiliki, maka hal tersebut dapat menjadi pengetahuan yang sangat bermanfaat untuk memahami pengguna atau konsumen.

Big data adalah sekumpulan data dalam ukuran yang dapat ditangkap, dikomunikasikan, diagregasi, disimpan dan dianalisis. Big data didapat dari berbagai sumber seperti klik di internet, transaksi online, user generated content dan media sosial. Big data memiliki karakter tersendiri (volume, variety, velocity, veracity dan value) yang dapat dengan mudah dibedakan dari data tradisional yang digunakan dalam analisis data. Dalam dunia bisnis yang kompetitif dan kompleks, perusahaan membutuhkan data untuk referensi pengambilan keputusan. Big data analytics dapat memberikan manfaat untuk meningkatkan transkasi dengan biaya efisien. Dibutuhkan metode baru dalam memahami perilaku konsumen, dan big data analytics menawarkan hal tersebut (Le \& Liaw, 2017).

Schroeck et al. (2012) mendefinisikan big data analytics (BDA) sebagai gabungan beberapa dimensi, mencakup area informasi yang luas, bentuk baru data dan analisis, informasi real-time, bentuk data media non tradisional, teknologi baru yang terbentuk oleh data, volume data yang besar dan data media sosial. Gantz dan Reinsel (2012) menyatakan bahwa BDA fokus pada tiga karakteristik, yaitu data, analisis data dan presentasi hasil dari analisis yang memungkinkan terjadinya nilai bisnis dalam hal produk atau layanan baru. Davenport dan Harris (2007b) mendeskripsikan BDA sebagai penggunaan data, statistik dan analisis kuantitatif melalui penjelasan dan model prediksi untuk memfasilitasi fakta yang dapat mempengaruhi keputusan dan langkah yang diambil manajemen. Lanskap e-commerce saat ini dipenuhi oleh big data yang digunakan untuk menyelesaikan permasalahan bisnis. Penggunaan big data berkembang pesat dengan adanya media sosial, internet, smartphone dan semua jenis teknologi baru yang dapat menghasilkan dan menangkap data (Akter \& Wamba, 2016).

Mengaplikasikan BDA dapat menjadi inovasi dan metode baru dalam bisnis e-commerce. Dengan melakukan BDA dapat meningkatkan nilai pada konsumen menggunakan teknologi untuk 
menganalisis data untuk disesuaikan dengan kebutuhan konsumen. Beberapa $e$-commerce besar yang telah mengaplikasikan BDA antara lain adalah Google, eBay, Amazon, Taobao, yang telah mendapatkan banyak peningkatan nilai bisnis dari hal tersebut. Setelah tahun 2017, teknik data analisis telah dinilai sebagai kebutuhan dan lanskap kompetisi bisnis, sehingga perusahaan perlu segera mulai beradaptasi pada tren penggunaan BDA dalam rangka bertahan di tengah dinamika pasar digital. Proses ini akan banyak berhubungan dengan data, skill dan sistem untuk membuat keunggulan yang kompetitif.

Konsep big data telah berkembang dan perlu diaplikasikan untuk meningkatkan strategi, prediksi dan pengambilan keputusan untuk hubungan konsumen yang lebih baik (Le \& Liaw, 2017). Pemanfaatan hasil pengetahuan dari analisis big data selanjutnya dapat digunakan untuk menjadi pedoman dalam memberikan pengalaman pelanggan yang lebih baik. Dalam konteks TIK, dipahami dalam konsep user experience (UX).

\section{User Experience}

Pada sekitar tahun 1990, Donald Norman merupakan salah satu penulis pertama yang menggunakan isitilah "user experience" dalam mendeskripsikan aspek pengalaman seseorang dengan sebuah sistem. Norman menjelaskan, ia memperkenalkan istilah UX karena mempercayai istilah "penggunaan" terlalu sempit untuk menggambarkan seluruh interaksi komuputer dan manusia. Pada periode yang hampir sama, penelitian Lauralee Alben menempatkan focus UX pada sensasi yang dirasakan pengguna, pemahaman mereka tentang bagaimana suatu hal bekerja, perasaan mereka saat menggunakannya, pencapaian tujuan dan juga seluruh konteks interaksi (Lallemand, Gronier, \& Koenig, 2015).

Marc Hassenzahl memberikan definisi UX sebagai sebuah momen yang menyangkut perasaan saat berinteraksi dengan suatu produk atau jasa. UX mampu menarik perhatian dari produk itu sendiri ke dalam emosi dan perasaan manusia dalam memahami sisi momen subjektif dari penggunaan produk. Ia juga menambahkan, UX yang baik adalah yang dapat memenuhi kebutuhan manusia melalui interaksi dengan suatu produk atau jasa. Dengan kata lain, UX berhubungan dengan kebutuhan dasar manusia yang menyukai adanya keterkaitan, kompetensi atau stimulasi perasaan positif saat menggunakan produk atau jasa (Sproll et al., 2010). Dalam definisi lain disebutkan bahwa UX mencakup semua emosi, kepercayaan, preferensi, persepsi, respons, perilaku dan pencapaian yang muncul sebelum, disaat dan setelah menggunakan sebuah produk (Quiñones, Rusu, \& Rusu, 2018).

Pada level teoritis, UX sangat berhubungan dengan tren yang berkembang seputar teori aktivitas, distribusi kognitif, studi penggunaan dan desain emosi. Teori aktivitas dan distribusi kognitif melihat UX dalam pandangan komprehensif sebagai sesuatu yang kompleks dan fenomena sosial di mana teknologi berperan sebagai mediator antara pengguna dan aktivitasnya. Selanjutnya, pengguna tidak dilihat sebagai entitas yang berbeda, tapi merupakan bagian dari sistem, termasuk di dalamnya lingkungan, karakteristik pengguna, serta alat dan objek teknisnya. Sistem yang interaktif dapat memberikan pengalaman yang berharga sekaligus menjadi fungsi menarik dari UX yang diterapkan (Lallemand et al., 2015).

User experience merupakan faktor penting dalam pengambilan keputusan pembelian konsumen. Pada industri fashion, hal tersebut memiliki dampak yang kuat. Fashion adalah salah satu sektor besar di mana pengalaman berbelanja pengguna mempengaruhi komunikasi antarpertemanan di dalam kelompoknya, pengguna lain di dalam situs web, kekuatan merek, citra yang ditampilkan, sampai kemampuan perusahaan dalam menarik perhatian konsumen yang sudah ada maupun konsumen baru (Peng, Liao, Wang, \& He, 2016).

\section{METODE PENELITIAN}

Penelitian ini menggunakan metode studi literatur dengan melakukan analisis data sekunder. Analisis data sekunder adalah metode analisis pada data yang sebelumnya sudah dikumpulkan oleh peneliti lainnya. Pemanfaatan data yang telah ada ini memberikan banyak pilihan pada peneliti yang menghadapi waktu dan sumber terbatas. Analisis data sekunder merupakan latihan empiris yang 
mengaplikasikan basis penelitian yang sama dengan penggunaan data utama dan memiliki langkahlangkah yang harus diikuti selayaknya metode penelitian lainnya, sehingga metode ini memiliki langkah sistematis dengan prosedur dan evaluasi yang telah ditentukan (Johnston, 2014).

Langkah pertama adalah proses pengembangan pertanyaan penelitian. Dalam penelitian ini, pertanyaan penelitiannya adalah, bagaimana pemanfaatan TIK dalam industri fashion di Indonesia? Langkah kedua adalah mengidentifikasi data yang tersedia, dimana pada penelitian ini mengacu pada literature review yang berfokus dalam area TIK dalam konteks $e$-commerce, big data analytics, user experience dan industri fashion di Indonesia. Terakhir adalah melakukan evaluasi data, dimana disini dilakukan pengecekan terhadap kualitas data yang telah dikumpulkan.

\section{HASIL PENELITIAN}

TIK di definisikan sebagai sekumpulan komponen teknologi yang diatur dalam sebuah sistem informasi berbasis komputer. Komputer adalah alat yang efektif untuk mengumpulkan, memanipulasi dan mendistribusikan informasi. TIK dapat membantu organisasi dalam banyak hal, seperti mempercepat pengambilan keputusan strategis, memberikan kepastian yang lebih terukur dan meningkatkan kepercayaan penggunanya (Darwis, 2013).

Korpelainen (2011) mengidentifikasikan empat teori dan model TIK yang paling banyak digunakan dalam pemanfaatan TIK. Pertama adalah The Technological Acceptance Model (TAM) oleh Davis (1986), kedua, The Theory of Reasoned Action (TRA), ketiga, The Theory of Planned Behaviour dan yang terakhir adalah The Diffusion of Innovation (DOI) model.

Dalam konteks organisasi, dikenal sebuah framework yang banyak dipakai dalam pemanfaatan TIK yaitu The Technology, Organization, Environment (TOE) framework. Untuk melihat lebih jauh pemanfaatan TIK, framework TOE konsisten menggunakan model DOI yang memiliki basis teori kuat dan konsisten secara empiris sehingga dapat menyediakan aplikasi potensial dalam berbagai konteks (Setiowati et al., 2015).

Hasil penelitian yang menggunakan framework TOE ini menunjukkan bahwa teknologi, organisasi dan lingkungan menjadi faktor penting dalam pengadopsian TIK dalam industri fashion. Dalam kaitannya dengan faktor teknologi, kompleksitas, kemampuan uji coba, dan observasi adalah tiga faktor yang mempengaruhi adopsi TIK dalam industri fashion. Studi literatur juga membuktikan bahwa pemimpin perusahaan yang memiliki jiwa entrepreneurial tinggi, mampu mengambil risiko, inovatif dan kreatif akan berpengaruh pada kesiapan perusahaan dalam menerapkan TIK di perusahaan (Setiowati et al., 2015). Apabila kita memahami lebih dalam, terdapat faktor "lingkungan" yang menjadi salah satu faktor penting dalam pengadopsian TIK. Pemerintah dapat lebih fokus untuk membuat program atau mendorong para pengusaha di industi fashion agar lebih banyak lagi menggunakan TIK dalam aktivitas penjualannya. Penggunaan TIK dalam bisnis dapat memberi pengaruh besar kapabilitas marketing yang lebih mumpuni.

Untuk mencapai pertumbuhan dan kepemimpinan pasar, adaptasi TIK dapat menjadi salah satu strategi dalam merancang orientasi masa depan organisasi. Hal ini juga sejalan dengan kemampuan organisasi untuk membangun komitmen jangka panjang dengan pemangku kepentingan utama seperti pelanggan, karyawan, supplier, partners, pemegang saham, publik dan komunitas dengan menggunakan implementasi TIK. Untuk tetap berada di dalam kompetisi, organisasi perlu terus melakukan inovasi dalam pengembangan barang dan jasa, agar tidak tersisih dari kompetisi pasar (Andadari, Priyanto, \& Haryanto, 2016).

Pada penelitian Darwis (2013) sektor ekonomi kreatif di Indonesia dinyatakan belum menggunakan TIK secara maksimal. Dalam penelitian penggunaan e-commerce dalam kompetisi perusahaan, terlihat bahwa penggunaan e-commerce di Indonesia masih sangat terbatas. Dijelaskan bahwa beberapa perusahaan belum menggunakan e-commerce sebagai alat berbisnis. Sehingga kemampuan e-commerce belum benar-benar dimanfaatkan. Industri kreatif nasional perlu lebih matang dalam memahami teknologi dan memperhatikan tren dalam TIK yang terus berubah. Dukungan dari berbagai pihak seperti akademisi, pengusaha dan pemerintah sangat dibutuhkan untuk menumbuhkan sinergi dan ketahanan ekonomi nasional (Darwis, 2013). 
Corporate Research Foundation menemukan bahwa salah satu kunci kesuksesan sebuah perusahaan adalah kekuatan inovasi. Inovasi memerlukan dukungan sumber daya manusia dengan kreativitas tinggi di perusahaan. Inovasi semacam ini akan mampu membuat suatu hal yang baru dan membuat perusahaan memiliki posisi yang kuat. Sebuah perusahaan yang kuat dan memposisikan dirinya sebagai perusahaan yang inovatif akan mampu terus meningkatkan performa perusahaannya. Dalam marketing, inovasi dibagi tiga kategori, yaitu inovasi kreatif, inovasi adaptif dan inovasi administratif. Inovasi kreatif adalah melakukan suatu hal yang belum pernah dilakukan sebelumnya, mencakup inovasi bermanfaat dalam bentuk produk, layanan atau metode. Inovasi adaptif lebih berhubungan pada kombinasi atau modifikasi beberapa elemen dengan menggunakan cara yang baru. Inovasi administratif adalah inovasi yang mampu menghasilkan operasional perusahaan yang lebih efektif dan efisien (Musthofa, 2017).

E-commerce sebagai metode elektronik dalam melakukan aktivitas bisnis, terutama dengan penggunaan internet, dapat menjadi inovasi bisnis modern yang ditujukan untuk memenuhi kebutuhan organisasi, penjual dan pembeli dengan tujuan efisiensi biaya dan meningkatkan kualitas barang, jasa serta kecepatan jasa pengantaran (Ruikar, Kirti. Anumba, 2008). Dalam implementasinya pada industri fashion, e-commerce dapat menjadi sebuah inovasi yang mampu memberikan pengalaman berbelanja lebih baik. Konsumen dapat melakukan belanja online dari rumah dan barang juga akan diantar kerumah, sehingga membantu efisiensi biaya kepada dua belah pihak, yaitu penjual dan pembeli.

Namun berdasarkan data yang dikeluarkan Badan Ekonomi Kreatif (“BEKRAF Data,” n.d.), pada tahun 2016, diketahui jumlah usaha atau perusahaan ekonomi kreatif yang memanfaatkan media internet dan penerapan e-commerce pada subsektor fashion yaitu sebesar 51,210 dari total 89,685 perusahaan. Masih terdapa 38,475 perusahaan yang belum memanfaatkan TIK dalam kegiatan usahanya. Apabila angka pemanfaatan TIK dapat ditingkatkan, bisa dipastikan bahwa subsektor fashion akan menghasilkan pendapatan yang lebih besar lagi. Hal tersebut tentunya akan berpengaruh pada peningkatan ekonomi kreatif di Indonesia. Perlu diingat bahwa pelaku industri fashion di Indonesia bukan hanya perusahaan di kota-kota besar. Banyaknya small-medium enterprises (SME's) di dalam industri fashion juga perlu mendapatkan perhatian dalam hal implementasi TIK.

Penelitian yang dilakukan Musthofa (2017) menunjukkan, inovasi sangat dibutuhkan dalam meningkatkan performa bisnis. Kesuksesan inovasi perusahaan akan mampu membuat kinerja yang lebih baik, sehingga apabila industri fashion dalam negeri memiliki sumber daya yang mampu berinovasi, maka kinerja bisnis pun akan meningkat. Dalam industri fashion, inovasi merupakan faktor penting dalam keputusan pembelian konsumen. Apabila perusahaan-perusahaan fashion di Indonesia tidak mampu mengikuti tren dan berinovasi, maka perusahaan tersebut akan terlihat "tua" di mata konsumen, sehingga dapat menyebabkan konsumen tidak lagi melakukan pembelian dan memberikan efek pada perusahaan (Musthofa, 2017).

E-commerce dapat menjadi konsep inovasi dalam penjualan atau pembelian barang dan jasa dengan menggunakan World Wide Web, sehingga pembelian mau pun pertukaran produk dan jasa dalam usaha fashion dapat memanfaatkan jaringan informasi melalui internet (Darwis, 2013). Hal ini tidak saja memudahkan konsumen dalam mendapatkan barang atau jasa yang mereka butuhkan, tetapi juga memberikan kemudahan bagi penjual untuk memasarkan produk atau jasa nya secara lebih luas lagi.

Apabila perusahaan fashion telah mengimplementasikan e-commerce di dalam bisnisnya, maka situs e-commerce setiap harinya akan menghasilkan data perilaku pengguna dalam jumlah yang sangat besar, sehingga jika perusahaan mampu memahami data-data yang tersedia ini, selanjutnya perusahaan dapat mengenal lebih jauh mengenai pengguna atau konsumen mereka dan pada akhirnya dapat membangun hubungan yang lebih baik dengan konsumen, karena big data dapat menerjemahkan data konsumen menjadi bentuk pengetahuan yang bernilai ( $\mathrm{Hu}, 2018)$. Melakukan analisis big data dapat menjadi inovasi dan metode baru dalam bisnis e-commerce (Le \& Liaw, 2017).

Penelitian Le \& Liauw (2017) menunjukkan, terdapat empat faktor positif dalam pengaplikasian big data analytics (BDA) yang dapat bermanfaat bagi perusahaan, diantaranya: (1) Information search. Information search mengindikasikan informasi dan layanan pencarian yang 
berkualitas. Sebuah situs yang menggunakan alat BDA dapat melakukan filtrasi dan menyampaikan data pada konsumen dengan tepat dan dalam jumlah besar, karena big data adalah tentang relevansi dan penawaran produk atau jasa yang tepat, pada orang yang tepat, melalui medium yang tepat, dengan harga yang tepat dan di waktu yang tepat; (2) Recommendation System. Sistem ini dilakukan oleh banyak situs terkenal seperti Netflix, Amazon, eBay dan situs retail yang memberikan rekomendasi pada produk atau jasa yang disukai konsumen. Hal ini berhubungan dengan informasi konsumen sesuai preferensi yang mereka pilih, lalu e-commerce memberikan pilihan sesuai dengan preferensi tersebut. Hal ini tentunya memberikan keuntungan untuk kedua belah pihak; (3) Dynamic Pricing. Strategi harga dinamis terjadi saat harga ditentukan berdasarkan pembeli, lokasi pembeli, produk dan waktu, dimana dalam penjualan dan pembalian produk harga dapat ditentukan dengan bebas dalam level transaksi individual; (4) Customer Services. Big data dapat secara drastis menaikkan kualitas layanan konsumen dan membuat mereka lebih bahagia. Dengan menggunakan data analisis secara mendalam, perusahaan dapat mengoptimasi layanan konsumen berdasarkan perilaku konsumen, posisi geografis, tren pencarian dan komplain, apabila sebelumnya pernah membuat komplain.

Dengan melakukan BDA perusahaan dapat menggali lebih dalam berbagai informasi yang dapat menghasilkan pengetahuan berupa nilai-nilai yang sesuai dengan apa yang menjadi kebutuhan dan keinginan konsumen. Dalam menerjemahkan hasil analisis data yang tersedia, pelaku usaha dapat mengimplementasikannya dalam bentuk yang dapat langsung dirasakan pengguna yaitu melalui user experience (UX). Pada definisi yang telah dituliskan sebelumnya, UX meliputi semua emosi, kepercayaan, preferensi, persepsi, respons, perilaku dan pencapaian yang muncul sebelum, disaat dan setelah menggunakan sebuah produk atau jasa (Quiñones et al., 2018). Apabila perusahaan dapat melakukan penerapan UX sesuai dengan hasil analisis big data, maka hal tersebut dapat memberikan pengaruh positif terhadap pengalaman belanja pengguna. Pangguna akan merasa lebih dimengerti dan dikenali dengan baik oleh perusahaan.

Pengalaman konsumen dalam industri fashion sangatlah vital (Casidy, Nuryana, \& Hati, 2015). Pelaku industri perlu melakukan usaha lebih besar dalam mempertahankan posisi dan keberlanjutan bisnis kedepannya. Konsep UX menjadi sangat relevan dengan bagaimana sebuah perusahaan memberikan pengalaman terbaik pada konsumennya. Karena UX yang baik akan mampu menghasilkan pengalaman yang bersifat positif bagi konsumen (Sproll et al., 2010).

UX adalah seluruh pengalaman yang dirasakan pengguna saat menggunakan sebuah produk atau jasa. Penelitian mengenai UX banyak dilakukan sehubungan dengan perkembangan teknologi internet. UX di dalam pengalaman seorang konsumen dalam melakukan belanja online, mencakup mulai dari tampilan yang dilihat pada situs web, melihat detail produk, memesan barang, melakukan pembayaran, pengantaran barang, kondisi barang, dan seluruh pengalaman yang dirasakan sampai barang tersebut sampai ke tangan konsumen. Sehingga bisa dikatakan bahwa UX saat ini tidak hanya terbatas pada aplikasinya dalam human-computer interaction (HCI) saja, melainkan juga sampai pada interaksi yang terjadi diluar medium komputer.

Industri fashion telah berkembang sangat pesat dan memberikan pengaruh pada sektor ekonomi. Aktivitas penjualan produk fashion telah menjadi industri yang tidak hanya memberikan pengaruh secara ekonomi, tetapi juga pada sektor lain seperti politik dan budaya. Fashion juga merupakan bagian dari seni dan salah satu sumber utama dalam ekonomi kreatif (Indarti,. Peng, 2017). Pengembangan inovasi dalam industri ini tentunya akan memberikan pengaruh terhadap kemajuan industri fashion di Indonesia. Para pelaku industri perlu diberi arahan dan kemampuan dalam melakukan pengembangan TIK di dalam perusahaannya, karena fashion sejatinya bukan hanya sekadar pakaian, tetapi juga menyangkut gaya hidup (Ekonomi Kreatif \& Outlook, 2019).

Selain itu dalam industri fashion di Indonesia, terdapat juga contemporary modest fashion atau modest fashion yang memiliki andil besar dalam perkembangan industri. Saat ini modest fashion telah menjadi fenomena mendunia yang menghasilkan sebuah tren baru. Penggunaan pakaian yang mengacu pada nilai-nilai islami ini ikut membawa Indonesia menjadi pelopor tren fashion di pasar internasional. Pengaruh besar diawali oleh para desainer modest fashion yang tampil menarik di media sosial dan juga sebuah komunitas bernama Hijabers Community, hingga akhirnya menjadi 

tren yang mendunia dan berdampak pada perkembangan industri fashion di Indonesia (Indarti,. Peng, 2017).

Sejatinya industri fashion tanah air dapat menjadi sumber keberhasilan ekonomi kreatif di Indonesia apabila semua pelakunya dapat melakukan implementsi TIK dalam usahanya. Dalam sebuah penelitian menunjukkan, konsumen fashion di Indonesia sangat konsumtif dan lebih suka menghabiskan uang mereka pada produk baru yang dapat dijadikan simbol pencapaian, dibandingkan untuk membuat tabungan masa tua (Casidy et al., 2015). Tingginya kebutuhan terhadap fashion ini harus bisa dijadikan peluang oleh semua perusahaan fashion di Indonesia. Implementasi TIK pada industri fashion akan memberikan kesempatan besar bagi pelaku usaha lokal dalam menjangkau konsumen di dalam maupun luar negeri.

Data menunjukkan, industri fashion di Indonesia mampu memberikan kontribusi terhadap Produk Domestik Bruto (PDB) industri ekonomi kreatif sebesar 18,01 persen pada tahun 2016. Angka ini menjadikan subsektor fashion yang tertinggi kedua. Laju pertumbuhan PDB subsektor fashion ini meningkat 2,78 persen dari tahun sebelumnya. Secara nilai PDB yang dihasilkan subsektor fashion mencapai Rp 166,1 triliun, sedangkan nilai ekspornya pada tahun 2016 berada pada angka USD 10,9 juta dan memberikan kontribusi sebesar 54,54 persen terhadap total nilai ekspor ekonomi kreatif dengan negara tujuan ekspor yang utama adalah Amerika Serikat. Pada periode yang sama, diketahui jumlah usaha yang bergerak di bidang fashion mencapai 1.230.988 usaha. Subsektor fashion memberikan daya serap tenaga kerja sebesar 4.130.000 orang, dengan persentase pengusaha sebesar 94,41 persen belum memiliki badan usaha (Ekonomi Kreatif \& Outlook, 2019).

Fashion dinilai tidak hanya sebagai industri pakaian yang merupakan kebutuhan dasar manusia. Lebih dari itu, fashion menunjukkan gaya hidup seseorang dalam penampilan dan menjadi bagian dari identitas diri dan kelompok. Industri fashion juga memiliki peran penting karena kontribusinya yang sangat besar terhadap perekonomian. Besarnya kemampuan industri fashion dalam meningkatkan pendapatan nasional dan nilai ekspor, membuat fashion menjadi subsektor yang dinggulkan dalam ekonomi kreatif Indonesia (Ekonomi Kreatif \& Outlook, 2019). Pendampingan pemerintah terhadap pelaku industri fashion, terutama yang masih dalam bentuk SME atau UKM, juga perlu diperhatikan.

Bagi para pelaku UKM, seringkali mengalami dilema dalam mengadopsi teknologi baru, karena kurangnya pengetahuan dalam bidang TIK dan keterbatasan biaya perusahaan. Pada UKM di Indonesia, keunggulan relatif menjadi prediksi kuat dalam mengimplementasikan e-commerce. Data empiris lain menunjukkan, kemampuan melakukan inovasi pada level UKM sangat tergantung pada pemilik atau manajernya. Mereka hanya akan mengimplementasikan TIK apabila teknologi tersebut bisa disesuaikan dengan usaha yang mereka jalankan (Setiowati et al., 2015). Di sini dapat dilihat tantangan lain industri fashion di Indonesia, bahwa UKM belum melihat inovasi sebagai sesuatu yang perlu mereka lakukan. Dibutuhkan keberanian untuk melakukan perubahan dan inovasi, sehingga pemerintah juga perlu mengambil bagian untuk mendorong inovasi dan implementasi TIK di level UKM.

Industri fashion telah lama menjadi faktor penting secara sosial dan ekonomi di tengah masyarakat, karena pada dasarnya konsumen fashion sangat memikirkan penampilan mereka, sehingga mereka melakukan pembelian secara terus-menerus. Konsumen melihat fashion sebagai refleksi dari citra diri dan menggunakan produk fashion sebagai alat untuk menyampaikan pesan tersebut (Casidy et al., 2015).

Penerapan konsep TIK seperti e-commerce, big data analytics dan user experience akan mampu mendorong dan industri fashion dalam merengkuh pasar digital secara lebih luas lagi. Dapat dilihat pada pertumbuhan ekonomi di negara seperti Jepang, Korea dan Finlandia, yang secara teknis sangat maju dalam hal TIK. Pada negara-negara tersebut investasi dan produktivitasnya telah di dominasi oleh TIK, baik di sektor industri maupun ekonomi secara keseluruhan. Pada banyak penelitian juga menunjukkan bahwa TIK berkontribusi pada pertumbuhan ekonomi di negara berkembang dan sektor-sektor industri baru di negara maju (Lee et al., 2009).

Di tengah kompetisi yang semakin sengit, industri fashion perlu secara terus-menerus mendapat dukungan agar mampu menghadapi segala tantangan bisnis dan menaikkan angka penetrasi 
pasar internasional lebih tinggi lagi, karena saat ini baru mencapai 1,6 persen ("Kemenperin: Perluas Pasar Industri Fesyen Dalam Negeri Lewat Indonesia Fashion Week 2018," 2018). Dalam hal ini implementasi TIK dalam cakupan yang lebih besar akan dibutuhkan oleh para pelaku usaha. Namun pada mulanya, pelaku industri dapat memulai dari penggunaan e-commerce terlebih dahulu untuk meluaskan jangkauan pasarnya. Setelah usaha menjadi lebih berkembang, pelaku usaha dapat melakukan eksplorasi lain pada konsep TIK yang cocok digunakan dalam usahanya.

Teknologi informasi dapat menjadi kekuatan dalam sebuah bisnis, karena saat ini manusia menggunakan teknologi tidak hanya untuk kebutuhan professional, melainkan untuk kebutuhan personal juga dalam kapabilitasnya meningkatkan kualitas hidup. Sejatinya manusia memiliki berbagai peranan penting yang perlu dilakukannya, sehingga hal tersebut menyebabkan pelaku industri saat ini harus mampu berfokus pada strategi dalam menghadapi tekanan bisnis baru yang dihasilkan oleh perkembangan teknologi informasi (Darwis, 2013).

Konsumen industri fashion saat ini di dominasi oleh generasi millenials atau Gen Y, sehingga penggunaan TIK di dalam bisnis sangat dibutuhkan untuk menyasar generasi ini. Cara mereka dalam membeli produk lebih mengutamakan medium teknologi, berbeda dengan generasi sebelumnya. Sehingga segala informasi yang ada di internet akan dijadikan referensi bagi mereka dalam menentukan pembelian (Esteban-Santos, García Medina, Carey, \& Bellido-Pérez, 2018).

Dengan implementasi TIK yang berfokus pada konsep e-commerce, big data dan UX, pelaku industri fashion juga dapat memaksimalkan pemasaran pada konsumen. Tidak berhenti di situ, pelaku industri juga dapat mempertahankan hubungan baik dengan konsumen lama dan merambah pasar lainnya untuk menjangkau konsumen baru. Pada akhirnya dengan pemanfaatan TIK di dalam perusahaan, diharapkan ke depannya pelaku industri fashion Indonesia dapat lebih banyak lagi yang mampu bersaing di pasar global, sehingga pada level UKM sekalipun bisa menjual produknya sampai ke luar negeri dan mendapatkan pelanggan yang tidak dari Indonesia saja. Dengan begitu kompetensi pelaku industri juga dapat ikut meningkat dan menaikkan kualitas industri fashion itu sendiri. Pemerintah dapat melakukan pembinaan, pelatihan dan pendampingan pada pelaku industri fashion di level UKM sehingga mereka memiliki keberanian untuk mengadopsi teknologi informasi dan komunikasi yang lebih maju lagi dalam usahanya.

Dari konsep yang telah dijelaskan sebelumnya, dapat dilihat bahwa pemanfaatan TIK dalam industri fashion dapat membawa pada kemajuan perusahaan. Hal ini disebabkan karena TIK dapat memberikan peluang untuk menjangkau lebih banyak konsumen dan menyediakan infrastruktur dengan biaya rendah untuk pengembangan bisnis. Pengusaha fashion dapat dengan mudah mencoba beberapa alternatif TIK seperti e-commerce, lalu memanfaatkan big data yang di dapat dari situs $e$ commerce, setelah itu menjadikan data tersebut sebagai landasan dalam menciptakan user experience yang lebih baik lagi. Sehingga bisnis dapat terus berinovasi dan memiliki kekuatan yang kompetitif.

Tantangan industri fashion Indonesia adalag melakukan peningkatan pada jumlah pelaku industri fashion yang pada tahun 2016, masih ada 38,475 perusahaan lagi yang belum memanfaatkan TIK dalam kegiatan usahanya. Industri fashion telah lama menjadi faktor penting secara sosial dan ekonomi di tengah masyarakat dan kenyataan tersebut tidak akan berubah dalam waktu dekat, sehingga peluang pada pengembangan industri ini masih sangat besar.

Implementasi e-commerce dalam industri fashion dapat bermanfaat bagi kebutuhan organisasi, penjual dan pembeli yang mampu menghasilkan efisiensi biaya dan meningkatkan kualitas barang, jasa dan peningkatan kecepatan jasa pengantaran, sehingga dengan memanfaatkan teknologi e-commerce pelaku industri fashion juga dapat memanfaatkan banyak hal transformatif seperti melakukan layanan pelanggan secara real-time, persaingan harga yang dinamis, penawaran produk yang dapat dibuat lebih personal atau peningkatan dalam kemudahan interaksi dengan konsumen.

\section{KESIMPULAN}

Dengan prediksi jumlah besarnya big data pada tahun 2020 yang mencapai lebih dari 35 zettabytes, pelaku industri fashion Indonesia perlu mulai mengaplikasikannya agar dapat meraih potensi besar seperti beberapa e-commerce dunia antara lain Google, eBay, Amazon, Taobao, dan 
p-ISSN: 0853-4470 - Vol. 02, No. 01 (2019), pp. 8-18 lainnya. Perlu diketahui juga bahwa setelah tahun 2017, teknik data analisis telah dinilai sebagai kebutuhan dan lanskap kompetisi bisnis, sehingga perusahaan perlu segera mulai beradaptasi pada tren penggunaan big data dalam rangka bertahan di tengah dinamika pasar digital.

Pengalaman konsumen dalam industri fashion menjadi sebuah kekuatan penting yang perlu dibangun, karena industri ini sangat kompetitif. Pelaku industri perlu melakukan usaha lebih besar dalam mempertahankan posisi dan keberlanjutan bisnis kedepannya. Konsep UX menjadi relevan yakni bagaimana sebuah perusahaan memberikan pengalaman terbaik pada konsumennya. UX yang baik akan mampu menghasilkan pengalaman yang bersifat positif bagi konsumen.

\section{Daftar Pustaka}

Akter, S., \& Wamba, S. F. (2016). Big data analytics in E-commerce: a systematic review and agenda for future research. Electronic Markets, 26(2), 173-194. https://doi.org/10.1007/s12525-0160219-0

Andadari, R. K., Priyanto, S. H., \& Haryanto, J. O. (2016). Antecedents of Future Market Anticipation: a Better Understanding From the Fashion Industry in Indonesia. International Journal of Organizational Innovation, 8(3), 156-168. Retrieved from http://search.ebscohost.com/login.aspx?direct=true\&db=bth\&AN=112223607\&lang=it\&site=e host-live

BEKRAF Data. (n.d.). Retrieved March 25, 2019, from http://data.bekraf.go.id/index.php?r=site\%2Findex

Casidy, R., Nuryana, A. N., \& Hati, S. R. H. (2015). Linking fashion consciousness with Gen Y attitude towards prestige brands. Asia Pacific Journal of Marketing and Logistics, 27(3), 406420. https://doi.org/10.1108/APJML-09-2014-0136

Darwis, Y. (2013). the Urgency of Communication Media (E-Commerce) in Indonesia'S Creative Industry As an Effort To Increase Internatonal Business Competition: a Case Study of the Fashion Industry. International Journal of Organizational Innovation (Online), 5(3), 206-220. Retrieved

from http://search.proquest.com/docview/1419395366?accountid=10297\%5Cnhttp://sfx.cranfield.ac .uk/cranfield?url_ver=Z39.88-

2004\&rft_val_fmt=info:ofi/fmt:kev:mtx:journal\&genre=article\&sid=ProQ:ProQ:abiglobal\&ati tle $=$ THE+URGENCY+OF+COMMUNICATION+MEDIA+(E-COMMERCE

Ekonomi Kreatif, O., \& Outlook. (2019). Opus creative economy outlook 2019 1. Retrieved from http://www.bekraf.go.id/pustaka/page/89-opus-creative-economy-outlook-2019-indonesiaversion

Esteban-Santos, L., García Medina, I., Carey, L., \& Bellido-Pérez, E. (2018). Fashion bloggers: communication tools for the fashion industry. Journal of Fashion Marketing and Management, 22(3), 420-437. https://doi.org/10.1108/JFMM-10-2017-0101

Hendrayati, H., \& Gaffar, V. (2016). Innovation and Marketing Performance of Womenpreneur in Fashion Industry in Indonesia. Procedia - Social and Behavioral Sciences, 219, 299-306. https://doi.org/10.1016/j.sbspro.2016.04.034

$\mathrm{Hu}$, J. (2018). E-commerce big data computing platform system based on distributed computing logistics information. Cluster Computing, 6, 1-10. https://doi.org/10.1007/s10586-018-2074-6

Indarti,. Peng, L. S. (2017). Bridging local trend to global: Analysis of Indonesian Contemporary Modest Fashion.pdf. IEEE International Conference on Applied System Innovation. Retrieved from https://remote-lib.ui.ac.id:2111/stamp/stamp.jsp?tp=\&arnumber=7988267\&tag=1

Johnston, M. (2014). Secondary data analysis: A method of which the time has come. QqmlJournal.Net, 3(3), 619-626. https://doi.org/10.1159/000479695

Kemenperin: Perluas Pasar Industri Fesyen Dalam Negeri Lewat Indonesia Fashion Week 2018. (2018). Retrieved March 24, 2019, from http://www.kemenperin.go.id/artikel/19010/PerluasPasar-Industri-Fesyen-Dalam-Negeri-Lewat-Indonesia-Fashion-Week-2018?

Kollberg, M., \& Dreyer, H. (2006). Exploring the impact of ICT on integration in supply chain 
p-ISSN: 0853-4470 - Vol. 02, No. 01 (2019), pp. 8-18 control: A research model. Proceedings of the 2006 EurOMA Conference in ..., 285-294. Retrieved from http://www.sintef.com/globalassets/project/smartlog/publikasjoner/2006/2006kollberg-dreyer.pdf

Lallemand, C., Gronier, G., \& Koenig, V. (2015). User experience: A concept without consensus? Exploring practitioners' perspectives through an international survey. Computers in Human Behavior, 43, 35-48. https://doi.org/10.1016/j.chb.2014.10.048

Le, T. M., \& Liaw, S. Y. (2017). Effects of pros and cons of applying big data analytics to consumers' responses in an e-commerce context. Sustainability (Switzerland), 9(5). https://doi.org/10.3390/su9050798

Lee, S., Kim, M. S., \& Park, Y. (2009). ICT Co-evolution and Korean ICT strategy-An analysis based on patent data. Telecommunications Policy, 33(5-6), 253-271. https://doi.org/10.1016/j.telpol.2009.02.004

Musthofa. (2017). the Effect of Entrepreneurial Competency on Product Innovation and Business Performance: Empirical Cases of Fashion Business in Central Java, Indonesia. Researchers World: Journal of Arts, Science and Commerce, VIII(2), 13-21. https://doi.org/10.18843/rwjasc/v8i2/02

Peng, L., Liao, Q., Wang, X., \& He, X. (2016). Factors affecting female user information adoption: an empirical investigation on fashion shopping guide websites. Electronic Commerce Research, 16(2), 145-169. https://doi.org/10.1007/s10660-016-9213-z

Quiñones, D., Rusu, C., \& Rusu, V. (2018). A methodology to develop usability/user experience heuristics. Computer Standards and Interfaces, 59(November 2017), 109-129. https://doi.org/10.1016/j.csi.2018.03.002.

Rachmawati, D, Dini S.F.A. (2018). Analisis Personal Branding Selegram Nonselebriti Akun Instragram @ Lippielust. Warta Ikatan Sarjana Komunikasi Indonesia, Vol. 1(1), 34-40

Ruikar, Kirti. Anumba, C. J. (2008). Fundamentals of e-Business. In E-business in construction (pp. 6-22).

Saraswati, M.S. (2018). Social Media and the Political Campaign Industry in Indonesia. Jurnal Komunikasi Ikatan Sarjana Komunikasi Indonesia, Vol. 3(1), 51-65.

Setiowati, R., Hartoyo, Daryanto, H. K., \& Arifin, B. (2015). The effects of ICT adoption on marketing capabilities and business performance of Indonesian SMEs in the fashion industry Jakarta , Indonesia Hartoyo Department of Family and Consumer Sciences Bustanul Arifin Department of Agricultural Economics and Socia, 6(4), 10-11.

Sproll, S., Peissner, M., \& Sturm, C. (2010). From product concept to user experience, 473. https://doi.org/10.1145/1868914.1868968 